\title{
Legacies and Gifts: An Editorial Farewell
}

\author{
Nancy Beadie, Joy Williamson-Lott, Isaac Gottesman, and \\ Kathryn Nicholas
}

The history of History of Education Quarterly is rich with both intellectual and personal gifts from many scholars. As editors of $H E Q$ for the last five years, we have been continually grateful for the long tradition of probing historical scholarship that the journal builds upon as well as the current and ongoing investment of time and intellectual resources that many individuals make in the everyday work of cultivating new scholarship in the field. We'd like to take some space at the start of this - the last issue of volume 60, HEQ's sixtieth anniversary year, and the last of our editorship-to appreciate that tradition and acknowledge those contributions.

To honor an intellectual tradition is to make it new again. In our time with the journal, we sought to recognize and foster new perspectives, directions, and potential in the field in the form of special forums, features, and issues. One of the ways we are most challenged to make history new again is in our teaching. Thus the first of our special forums focused on the history of education as pedagogy. ${ }^{1}$ Nine innovative scholar-teachers reflected on their use of historical cases in the

\footnotetext{
${ }^{1}$ Joy Williamson-Lott and Nancy Beadie, "Forum on Teaching: Constructing Historical Cases," History of Education Quarterly 56, no. 1 (Feb. 2016), 115-16. Forum contributions appearing in that issue included Jack Dougherty, "Defining Purpose and Process in Teaching History with Case Studies," 116-25; Ansley T. Erickson, "Case Study as Common Text: Collaborating in and Broadening the Reach of History of Education," 125-33; Heather Lewis, "Future Teachers and Historical Habits of Mind: A Pedagogical Case Study," 133-40; Laura K. Muñoz, "Civil Rights, Educational Inequality, and Transnational Takes on the U.S. History Survey," 140-48; Karen Leroux, "Using Case Studies in the History of Education to Teach U.S. Women's and Gender History," 149-56; Valinda W. Littlefield, "Using the Educational Histories of Individuals to Complicate Standard Historical Narratives about Expanding Citizenship Rights and Opportunity," 157-63; Jon N. Hale, "Reconstructing the Southern Landscape: The History of Education and the Struggle for Civil Rights in Charleston, South Carolina," 163-71; and Isaac Gottsman and Michael Bowman, "The Significance of Geographic and Programmatic Context in Developing Historical Case Studies in Social Foundations in Teacher Education," 172-81.
} 
history of education to achieve a variety of pedagogical aims in a range of courses and settings. These included survey courses in American history that use educational biographies to help students recognize their own places in history and seminars that engage students in collective historical research as well as courses in gender and women's studies aiming to illuminate how gender is learned and changes over time and foundation courses in undergraduate and graduate teacher education that challenge students to think about issues of context in their own teaching.

A second way to renew the field is to bring historical perspective to current issues. In two policy forums, we invited groups of scholars to share their perspectives on enduring issues of education equity through historical assessments of two major policies and policy studies: the Elementary and Secondary Education Act (ESEA) and the Coleman Report. ${ }^{2}$ Later, in response to increased challenges to academic freedom here and around the world, we invited ten scholars from seven different countries to reflect on current issues of academic freedom from the perspective of their own historical research on the topic. $^{3}$

\footnotetext{
${ }^{2}$ The policy forum on the ESEA appeared in History of Education Quarterly 56, no. 2 (May 2016). Forum contributions appearing in that issue included Adam R. Nelson, "The Elementary and Secondary Act at Fifty: A Changing Federal Role in American Education," 258-61; Crystal R. Sanders, "Money Talks': The Elementary and Secondary Education Act of 1965 and the African-American Freedom Struggle in Mississippi," 361-67; Douglas S. Reed, "ESEA at Fifty: Education as StateBuilding," 368-74; and Susan L. Moffitt, "The State of Educational Improvement: The Legacy of ESEA Title I," 375-81. The policy on the Coleman Report appeared in History of Education Quarterly 57, no. 4 (Nov. 2017). Forum contributions appearing in that issue included Harvey Kantor and Robert Lowe, "Introduction: What Difference Did the Coleman Report Make?," 570-78; Zoë Burkholder, "The Perils of Integration: Conflicting Northern Black Responses to the Coleman Report in the Black Power Era, 1966-1974," 579-90; Victoria Cain, "From Sesame Street to Prime Time School Television: Educational Media in the Wake of the Coleman Report," 590-601; Leah N. Gordon, "If Opportunity Is Not Enough: Coleman and His Critics in the Era of Equality of Results," 601-16; and Ethan L. Hutt, "Seeing Like a State' in the Postwar Era: The Coleman Report, Longitudinal Datasets, and the Measurement of Human Capital," 615-25.

${ }^{3}$ The Forum on Academic Freedom appeared in History of Education Quarterly 58, no. 3 (Aug. 2018). Forum contributions appearing in that issue included Joy Ann Williamson-Lott, "Protecting Academic Freedom: Using the Past to Chart a Path Toward the Future," 420-22; Marjorie Heins, "A Pall of Orthodoxy over the Classroom': Lessons from the Great Keyishian Case," 423-28; Timothy Reese Cain, "Friendly Public Sentiment' and the Threats to Academic Freedom," 42835; Vania Markarian, "Authoritarian Legacies and Higher Education in Uruguay," 435-41; Hans-Joerg Tiede, "The Front Rank: On Tenure and the Role of the Faculty in the Defense of Academic Freedom," 441-47; Qiang Zha and Wenqin Shen, "The Paradox of Academic Freedom in the Chinese Context," 447-52;
} 
Similarly, in a feature in November 2016 we called "History of Education in the News," scholars brought historical insight and commentary to current events. In response to the Black Lives Matter movement and recent scholarship on the history of slavery in higher education, for that issue we solicited and published an essay by James D. Anderson and Christopher M. Span, "The Legacy of Slavery, Racism, and Contemporary Black Activism on Campus." 4 More recently, in response to the COVID-19 pandemic, we published "Higher Education Institutions Respond to Epidemics," an essay by James W. Thomas and Holly Ann Foster that surveys prior institutional responses to epidemics of cholera in the nineteenth century and the influenza epidemic of 1918.5

Another approach to renewal is to solicit scholarship that actively seeks to uncover new historical knowledge, mobilize untapped analytical potential, or synthesize underappreciated perspectives in the field. From the start of our editorship, the first in the journal's history to view the field and its work from the Pacific Rim, we had an interest in highlighting how a history of education that more richly encompassed the distinctive peoples, issues, and dynamics of the North American West could transform our understanding. In two special issues, we challenged the field to reimagine the history of education from that perspective, both by soliciting new work and by synthesizing existing scholarship around that focus in two historiographical essays called "Gateways to the West," Parts I and II. ${ }^{6}$ We are pleased that since then we have continued to receive and publish new manuscripts with a western focus.

Finally, as we looked forward to the future of HEQ beyond our editorship and backward over its history for this sixtieth anniversary volume, we commissioned three special forums and one special issue that intentionally draw upon seminal articles HEQ previously

Karen Graves, "A Matter of Public Concern: The First Amendment and Equal Employment for LGBT Educators," 453-60; Beth le Roux, "Repressive Tolerance in a Political Context: Academic Freedom in Apartheid South Africa," 461-66; and Anne Corbett and Claire Gordon, "Academic Freedom in Europe: The Central European University Affair and the Wider Lessons," 467-74.

${ }^{4}$ James D. Anderson and Christopher M. Span, "The Legacy of Slavery, Racism, and Contemporary Black Activism on Campus," History of Education Quarterly 56, no. 4 (Nov. 2016), 646-56.

${ }^{5}$ James W. Thomas and Holly Ann Foster, "Higher Education Institutions Respond to Epidemics," History of Education Quarterly 60, no. 2 (May 2020), 185-201.

${ }^{6}$ Nancy Beadie et al., "Gateways to the West, Part I: Education in the Shaping of the West," History of Education Quarterly 56, no. 3 (Aug. 2016), 418-44; and Nancy Beadie et al., "Gateways to the West, Part II: Education and the Making of Race, Place, and Culture in the West," History of Education Quarterly 57, no. 1 (Feb. 2017), 94-126. 
published as springboards for considering new ideas and directions in the field. Thus, Carl Kaestle's classic 1992 piece, "Standards of Evidence in Historical Research: How Do We Know When We Know?" spawned a set of new essays by David G. Garcia and Tara J. Yosso, Kabria Baumgartner, and Ansley T. Erickson that address issues of silence and the limits of generalization in research in the field. $^{7}$

Next, taking up classic essays on "Politics of Knowledge" by Ellen Condliffe Lagemann, James D. Anderson, and Mary Ann Dzuback (all originating as History of Education Society (HES) presidential or American Educational Research Association vice presidential addresses), four scholars-Jessica Blatt, Christopher P. Loss, Linda M. Perkins, and Nidia Bañuelos-outline needs and opportunities for scholarship, bringing new angles to the topic. ${ }^{8}$ Continuing this idea of critically renewing the field, Kate Rousmaniere and Jason Ellis penned a provocative essay they called "Professor Bailyn, Meet Professor Baynton" to introduce a special issue they edited on "The New Disability History." "Now, for this last issue of the sixtieth anniversary volume, we build on seminal HEQ essays by Victoria-María McDonald, Eileen H. Tamura, and K. Tsianina Lomawaima to publish five "Reflections on Education, Ethnicity, and Race" by Rosina Lozano, Stephanie Hinnershitz, Derek Taira, Liping Bu, and Kim Cary Warren, all of whom explore new directions and conceptualizations in the field. ${ }^{10}$

7 "How Do We Know When We Know?: Reflections on Method," History of Education Quarterly 60, no. 1 (Feb. 2020), 58. Forum contributions appearing in the issue included David G. Garcia and Tara J. Yosso, "Recovering Our Past: A Methodological Reflection," 59-72; Kabria Baumgartner, "Searching for Sarah: Black Girlhood, Education, and the Archive," 73-85; and Ansley T. Erickson, "How/Should We Generalize?" 86-97.

8 "Not Simply Academic: Perspectives on the Politics of Knowledge," History of Education Quarterly 60, no. 2 (May 2020), 202. Forum contributions appearing in the issue included Jessica Blatt, "Institutional Logics and the Limits of Social Science Knowledge," 203-13; Christopher P. Loss, "No Operation in an Academic Ivory Tower': World War II and the Politics of Social Knowledge," 214-27; Linda M. Perkins, "Race, Gender, Philanthropy and the Politics of Knowledge," 228-45; and Nidia Bañuelos, "Why We Need More Histories of Low-Status Institutions," 246-60.

${ }^{9}$ Jason Ellis and Kate Rousmaniere, "Professor Bailyn, Meet Professor Baynton: The 'New Disability History' of Education," History of Education Quarterly 60, no. 3 (Aug. 2020), 285-94.

10 "Extending the Conversation: Education, Ethnicity, and Race," History of Education Quarterly 60, no. 4 (Nov. 2020), 611. Forum contributions appearing in the issue included: Rosina Lozano, "New Directions in Latino/a/x Histories of Education: Comparative Studies in Race, Language, Law, and Higher Education," 612-622; Stephanie Hinnershitz, "Across the Divides: Beyond School, Nation, and 
The work of these authors and the authors of the many other articles published over the twenty issues HEQ published under our editorship is a great gift. Every work of genuine and serious scholarship is an act of faith, love, and life that we appreciate all the more in these challenging times. This human generosity, and our appreciation of it, is even greater when the work is largely hidden from view. Taking the research and ideas of others seriously enough to provide one's considered and well-informed review and assessment of italmost always anonymously-is genuine giving. We are deeply grateful for the many scholars - 245 of them to be exact - who over five years have given that gift (many multiple times!) and in the process made our work as editors possible and, we believe, more constructive. In our role we have tried to honor and acknowledge that work by keeping reviewers informed about editorial decisions and helping authors to appreciate the generosity, value, and importance of the feedback they receive.

A sense of the formidable effort of joint munificence this represented is suggested by the numbers. Over our term as editors, we have handled 445 unique manuscripts. This total does not reflect the number of times we saw a manuscript through multiple rounds. In addition, we published reviews of 158 books. Those books come from fifty-seven different publishers, and the reviewers represent 109 different colleges and universities. Truly this work by authors; reviewers; our formidable book review editor, Isaac Gottesman; and his former assistants, Jennifer Gallagher and Amber Graeber, is to be celebrated.

Lastly, we want to thank all the members of the HEQ editorial board, the HES board-who are all acknowledged in the front matter of every HEQ issue - and the society itself, who have supported the journal over the years. As we all know, appreciation and generosity are necessarily mutual. Your moral support kept us going, and we trust it will extend long into the future. Our appreciation further extends to the colleagueship of compatriots in the work, including the graduate students at the University of Washington who collaborated with us, especially in the first years as we brainstormed and developed possibilities for our editorship. The most dedicated, best

the 1965 Immigration Act in the History of Asian American Education," 623-631; Derek Taira, "We Are Our History': Reviewing the History of Education in Hawai'i and Oceania," 632-643; Liping Bu, "Confronting Race and Ethnicity: Education and Cultural Identity for Immigrants and Students from Asia," 644-656; and Kim Cary Warren, "Rethinking Racial, Ethnoracial, and Imperial Categories: Key Concepts in Comparative Race Studies in the History of Education," 657-669. 
organized, and most forgiving of these eventually became our inimitable managing editor, Kathy Nicholas.

That league of editorial compatriots began for us with the editors at the University of Illinois from whom we took over work on the journal over five years ago and it continues with the editors at the University of Massachusetts at Lowell, who now take over the work from us. At the University of Illinois, Yoon Pak, Chris Span, and Jim Anderson put key systems in place that served the journal well, even as we refined and modified them, as will our successors, editors A. J. Angulo, Jack Schneider, and Chris Carlsmith, along with Managing Editor Kim Tolley and book review editors Ethan Hutt and Sonya Ramsey. We welcome you and wish you well as you shepherd this formidable intellectual tradition and these many legacies and gifts. 